INTERNATIONAL JOURNAL OF RESEARCHES IN BIOSCIENCES, AGRICULTURE AND TECHNOLOGY (C) VISHWASHANTI MULTIPURPOSE SOCIETY (Global Peace Multipurpose Society) R. No. MH-659/13(N) www.vmsindia.org

\title{
SOIL CHARACTERISTICS ASSOCIATED WITH BRYOPHYTES OF MELGHAT FOREST
}

\author{
WANKHEDE T.B. \\ Department of Botany Shri Shivaji Science College, Amravati \\ E-mail: tusharwan@gmail.com
}

\begin{abstract}
:
Bryophytes make a significant contribution to the floral diversity of this "watery planet" and since its inception constitute an important component of the forest ecosystem being the first colonizers on variety of habitats. They are highly specific group of plants with about 25,000 species distributed the world over, making it the second largest group of land plants after angiosperms. Certain bryophyte occurs at specific $\mathrm{pH}$ range and their presence can be used as indicator of soil $\mathrm{pH}$. Bryophytes envelops the forest cover with moisture, temperature, prevents soil erosion can be used to monitor water pollution while many mosses are good indicators of air pollution. Present investigation shows that bryophytic vegetation of Melghat forest responds to soil texture, soil $\mathrm{pH}$, and soil nutrients and also exhibits specificity to electrical conductivity, organic matter and soil depth. They are confined to slight acidic, moderately neutral and medium basic soil depending upon geographical distribution and also signifying specificity with the environmental conditions.
\end{abstract}

Key words: Bryophytes, Soil Chemistry, Bio influence

\section{INTRODUCTION:}

Soil is a vibrant ever-changing element and characterized not only by chemical and geological properties but also physical and biological characteristics. The quality of soil is rather dynamic and is the end product of soil degrative or conservative processes. It is controlled by chemical, physical and biological components of the soil and their interactions (Kennedy and Papendick, 1995). Bryophytes are more common in humid areas and during rainy seasons, but usually show a preference for microclimatic niches such as crevices of rocks and trees and the vicinity of small shady springs and can grow on wide range of substratum (Shaw and Renzaglia, 2004). However, Ganopadhyay (1992) showed that edaphic factors like organic matter, EC, temperature and $\mathrm{N}, \mathrm{P}, \mathrm{K}$; ratio has a significant effect on vegetation as well as soil microflora. Bowen and Rovira (1999) believed that, the rhizosphere is a partnership between the plant, soil and soil organisms. Plant provide carbon and food source for soil organisms that bind the soil particles into aggregates and recycle soil nutrients while the soil provides the habitat, water and mineral nutrients for both soil organisms and plants.

Patel (1968) divided the soils of Melghat forest into Bouldery soil, Clay, Alluvium, Lateritic loam and Gritty loam type. The bouldery soil occurs mostly across the Melghat region and confined to the slopes. The soils found well drained and lacks moisture during dry season. The texture of soil varies as clay, loam or sandy loam and best vegetation of plants grow on this type of soil. The clay soil dominantly found in depressions and on flat areas. The clay soil generally found as black in colour and fertile. The soil occurs at low-lying areas and plains supporting good forest. The riversides and basins along the main rivers like Sipna, Gadga etc. represents a small area of alluvium type of soil. It varies from fine light brown silt to coarse masses favouring tree vegetation. The lateritic loam represents typical tropical forest soil occurring at hilltops and plateaus. It has characteristic red brown colour due to presence of iron oxides with small stones. Chikhaldara plateau generally resembles closely to lateritic showing fertility and trees growth. However, the Gritty loam occurs on the lower hills and derived from the weathering of the grey basalt 
rock. Besides its fair quality, it is not fertile in real sense to favour tree growth. Soil serves as a medium for plant vegetation on the earth's surface. It consists of minerals as well as organic matter and air exhibits peculiar characteristics impressed by the physical and chemical action of tree roots, debris and forest humus. The soil dynamics are directly proportional to the growth of plants, ground cover vegetation, activity of organisms and climatic effects. Hence, several factors like climate, topology, organisms and parent material form a soil medium where root grows, anchor plants to absorb nutrients from soil and establishes a population or community (Brady and Weil, 2008).

\section{MATERIAL AND METHODS:}

\section{Survey and site selection}

For survey in Melghat forest, permission was taken by Principal Chief Conservator of Forest, Nagpur under wildlife protection rules, 1975. The core area of Melghat forest like Chikhaldara plateau, Semadoh, Kolkhas, Ghatang, Gugamal, Tarubanda, Belkund and their allied sites like Churani, Vairat, Bhimkund, Amazari, Koha, Khongada, Parsapur, Raipur and Makhala were selected for the study.

\section{Soil analysis}

Quantitative soil analysis was preferred than qualitative analysis for study of soil chemistry so that actual nutrient level can be assessed. Soil physico-chemical properties like Colour, Texture, pH, Temperature, TDS (Total Dissolved Solids), EC (Electric Conductivity) were evaluated using standard quality VSI Soil and Water Analysis Kit. The nutrient constitution like N (Nitrogen), P (Phosphorus), K (Potassium) and \% C (Organic Carbon) were analysed in laboratory as per the procedure and protocols of Jackson (1973) and Mishra (1968).

The organic carbon from soil was determined by wet oxidation method as described by Nelson and Sommers, (1996).

\section{RESULT \& DISCUSSION:}

Soil Analysis and bryophytic distribution:

A) Soil texture: The soil texture exhibits different characteristics at different locations. The upper plateau of Chikhaldara showed bouldery type of brown coloured soil across the allied regions also. However, the lower parts at the slopes like Semadoh, Kolkhas, and Tarubanda represents red coloured lateritic type of soil. The region of Raipur, Makhala, and Ghatang exhibit mixed type of soil with some patches of gritty loam, brown coloured soil. The basins of rivers like Sipna, Gadga represents black alluvium type of soil and allied regions also showed black soil along with the plains also (Table: 1 ).

B) Soil pH: The pH value of the soil was observed in between 6.73 to 8.06 representing slight acidic, neutral and slight basic nature across the region (Table 1). However, variations in $\mathrm{pH}$ values were observed across the different sites and among different bryophytic plants during the course of investigations. Plants like Targionia sp. found at $\mathrm{pH}$ value 6.73 while Asterella sp. found at 8.06 $\mathrm{pH}$ value near Belkund. $\mathrm{pH}$ is a good measure of the intensity of acidity and alkalinity of the soilwater suspension and provides appropriate information about the chemical nature of soil. $\mathrm{pH}$ of soil depends upon relative amounts of adsorbed hydrogen and metallic ions. Most of the bryophytes species occurs at neutral nature of soil and hence represents good biological indicator or ecological indicators in Melghat forest (Katznelson, 1965)

C) Soil temperature $\left({ }^{\circ} \mathbf{C}\right)$ : The soil temperature observed in range of $16^{\circ} \mathrm{C}$ to $29.1^{\circ} \mathrm{C}$ among various samples, collected during the course of work (Table: 1). Notothylas sp. growing on brown coloured soil at Amazari showed lowest soil temperature of $16^{\circ} \mathrm{C}$ while the plant Hymenostylium sp. near Madaki exhibited highest soil temperature of $29.1^{\circ} \mathrm{C}$ collected during month of October (Fig: 1). The bryophytes occurring at low soil temperature showed maximum growth favouring prostrate or rosette 
type growth at Belkund, Amazari, and Chikhaldara with plants like Riccia sp. and Plagiochasma sp. The soil temperature also depends upon slope, latitude of land, distribution of land and water, vegetation cover, nature of the soil and height of the location from mean sea level (MSL). As bryophytes are shade and moisture loving plants, their distribution favours the low temperature, high moisture and availability of water sources (Wang et al., 1985).

D) Total dissolved soils (TDS): The total dissolved solids among the soil suspension observed in the range of $008 \mathrm{mg} / 1$ to $031 \mathrm{mg} / 1$. The plants growing in different habitat at different locations showed variations in values of total dissolved solids (Table: 1). The plant Folioceros $\mathrm{sp}$. of terrestrial habitat and found on red soil at Semadoh showed less TDS value of $008 \mathrm{mg} / \mathrm{L}$ while Asterella sp. at Belkund showed the highest TDS value of $031 \mathrm{mg} / \mathrm{L}$ collected during the rainy season. The total dissolved solids (TDS) offers on idea about presence of nutrients or salts present in soil with respect to concentration. Nutrient salts are important resources that limit the plant growth in tropical soil. The TDS range found in bryophytes of Melghat soil ranges from 008 to 031 mg/L (Table: 1). The plants like Anthoceros sp. and Folioceros sp. at Semadoh found in less TDS range while plants at Belkund and Koha like Asterella sp. and Plagiochasma sp. possess high TDS range as compared to others (Jordan and Herrera, 1981).

E) Electrical conductivity (EC): The electrical conductivity of soils of different locations was found in range between $0.073 \mathrm{mmhos} / \mathrm{cm}$ to 0.35 mmhos/cm (Table: 1). The terricolous hornwort Folioceros sp. found at Semadoh in red soil showed very less EC value of $0.073 \mathrm{mmhos} / \mathrm{cm}$ while Asterella sp. at Belkund showed 0.49 mmhos/cm. The electrical conductivity observed to be varying at different locations and habitats.

The electrical conductivity of the soil sample is the measure of current carrying capacity explaining the value of soluble salts present in it. The soil nutrient status in the rhizosphere will affect change in soil biological community, which ultimately has consequences on plant growth. The rhizosphere is a partnership between the plant, soil and soil organisms. Plants provide carbon and food source for soil organisms that bind the soil particles into aggregates and recycle soil nutrients while, the soil provides the habitat, water and mineral nutrients for both soil organisms and plants (Carling et al., 1979).

F) Nitrogen content (N): The presence of nitrogen in the soil contributes to the vegetation stability in any habitat. The Nitrogen contents vary in different locations of the Melghat forest. Highest Nitrogen content was observed in Koha region among Plagiochasma sp. with $501.7 \mathrm{~kg} / \mathrm{ha}$ and among Phaeoceros sp. at Semadoh region with $498 \mathrm{~kg} /$ ha collected during rainy season. The lower Nitrogen content were observed in Targionia sp. in black soil with saxicolous habitat with $134.1 \mathrm{~kg} /$ ha. However, most of the plants at different locations showed deficient to moderate nitrogen content in the soil. The terrestrial habitat of most of the plants showed moderate nitrogen content than the rupicolous or saxicolous habitat. The nitrogen content in the soil of Melghat forest and among bryophytic thalli ranges from 134-501 $\mathrm{kg} /$ ha (Table: 1). The nitrogen content found more in Belkund, Koha, Tarubanda region and few sites at Semadoh and Chikhaldara region. The plants like Plagiochasma sp., Asterella sp., Reboulia sp. and Anthoceros sp. in the region occurred in nitrogen rich soils of the forest with increase in vegetative growth. Low to moderate nitrogen contents found in the soils of Churani, Amazari, Gugamal and Ghatang showing good covering of bryophytes carpets. The organic matter formed from the decomposition of fallen debris is the most important constituent of the soil and the apex region of maximum biological activity. It is a primary source of plant nutrients, especially nitrogen and also determines the physical properties of the soil, like porosity and aeration (Ratnaparkhi, 2007). 
G) Phosphorus (P): The phosphorus is a major nutrient block in plant metabolism, growth and development. The occurrences of phosphorus observed were variable from negligible condition to rich condition. Higher phosphorus content observed in Semadoh region among Anthoceros sp. with $102 \mathrm{~kg} / \mathrm{ha}$ and among Plagiochasma sp. at Chikhaldara with $89.97 \mathrm{~kg} /$ ha collected during rainy season. However, lower phosphorus content was observed in nutrient deficient mosses growing on rocks along roadside or pools or pebbles like Hymenostylium sp. with $14.50 \mathrm{~kg} / \mathrm{ha}$ and among Plagiochasma intermedium with 14.60 $\mathrm{kg} /$ ha growing on rocks of Gawilgarh in whitish soil. The moss Hyophila sp. also showed lesser content of phosphorus with $16.50 \mathrm{~kg} /$ ha growing on rocks at Madaki on Paratwada - Chikhaldara road. These soil samples collected during the month of December where winter season was prevailed in the region. The phosphorus content among bryophytes soil varies from moderate to high contents (Table:1) but deficient in the plants like Plagiochasma intermedium and among mosses growing on saxicolous habitats like Funaria sp., Hyophila sp. and Hymenostylium sp. due to epilithic substratum and nutrient deficient condition (Fig:1). However, the Chikhaldara and Semadoh exhibits high phosphate concentration in soil and the regions found rich in vegetation cover with maximum density of plants (Ratnaparkhi, 2007).

H) Potassium (K) : The potassium content among the soils of Melghat region was found quite higher and sufficient with respect to bryophytes (Table: 1) and parallel to other species like Bryum sp. or Anthoceros sp. etc. The lowest potassium content was observed in Funaria sp. at Gugamal forest with $200.48 \mathrm{~kg} / \mathrm{ha}$ at terricolous habitat. The potassium played an important role in nutrient uptake and physiology of plant metabolism. The potassium contents among the soil of bryophytic thalli showed high value as compared to nitrogen and phosphorous. The regions like Koha,
Belkund, Semadoh and Ghatang showed high concentration of potassium while Chikhaldara and other allied areas showed moderate value of potassium. Potassium is major contributor to osmotic potential of plant cells by balancing the charge of both diffusible and non-diffusible ions. It also acts as an activator of many enzymes in physiological processes like photosynthesis, respiration, carbohydrates metabolism, protein synthesis and stomatal movements (Jain, 2006).

I) Organic Carbon (C \%): The percentage of organic carbon among the soils of bryophytes of Melghat forest ranges between minimum from $0.29 \%$ to $0.53 \%$ at maximum (Table: 1 ). The bryophyte species Cyathodium of rupicolous habitat showed less $0.29 \%$ organic carbon at Semadoh region while the species Folioceros, interestingly showed $0.53 \%$ of maximum value in reddish lateritic soil in saxicolous and terrestrial habitat. The variable value of organic carbon observed during present investigation but related to vegetation and community. The percentage of organic carbon in bryophytes of Melghat forest found in moderate range of $0.29 \%-0.53 \%$. The regions like Semadoh, Chikhaldara, Khongada and Ghatang exhibits high organic content in the soil as compared to other regions. Hence, these regions show good quality of vegetation and forest cover (Glime, 2006).

\section{J) Cation Exchange Capacity (CEC) :}

Bryophytes possess a typical cation exchange capacity (CEC) due to high concentrations of nonesterified pectates i.e. polyuronic acids called galacturonic acid within primary cell wall, than any of the other land plants (Clymo, 1963). These galacturonic acids have a carboxyl group $\left(\mathrm{COOH}^{+}\right)$ protruding on the outer surface of the wall. This carboxyl group freely exchanges its $\mathrm{H}^{+}$for other cations in its surroundings. $\mathrm{K}^{+}$ions often filter through the bryophyte layer and mostly bound on the bryophytes (Bates, 1982). Bryophytes have many exchange sites permitting differential binding of ions. Hence, the present investigations correlate with the findings of Glime (2006). From 
above discussion, it is noteworthy that fungi are often associated with rhizoids of bryophytes because large numbers of bryophytes are afforded the advantages of fungal partner relationships providing them with considerably more surface area for acquiring nutrients.

Dhore, (2002) reaffirmed the characteristics of Melghat soil as Lateritic, Clay, Alluvium and Bouldery of Murrum types. The regions like Chikhaldara plateau, Semadoh, Ghatang road represents red bouldery soil in patches showing less fertility, nutrient deficiency and less water holding capacity. Certain saxicolous habitat of bryophytes like Funaria hygrometrica, Targionia hypophylla observed commonly on this soil. Nutrient deficient bryophytes can easily attach to the substratum of such soil. However, the regions like Amazari, Belkund, Tarubanda, Kolkhas and Semadoh show red brown lateritic type of soil. This represents high content of ferric oxides. Hornworts like Anthoceros erectus, Folioceros udarii and mosses like Hyophila involuta, Funaria hygrometrica were found on such type of soil. Frequent black soil clay patches found at the riversides of Sipna and Dollar at Semadoh, Kolkhas and near small creeks or water bodies at Chikhaldara and allied regions. The blackish clay or alluvium soil found at Semadoh, Churani, Madaki and on the plains show rich fertility and water holding capacity. The terricolous plants like Riccia gangetica, Riccia discolor, Anthoceros erectus, Notothylas indica, Phaeoceros laevis and sometimes Plagiochasma appendiculatum were found on this type of soil. The bright coloured, yellow green, fluorescent Cyathodium tuberosum also found on forest soil in shady conditions during rainy seasons. The brownish colour of soil observed at Semadoh, Gugamal and Chikhaldara region showing plants like Targionia hypophylla, Hyophila involuta, Bryum coronatum etc. in terricolous and rupicolous habitat. The colour of soil may be due to presence of humus (Ratnaparkhi, 2007). The mosses like Brachythemium turgidum and Stereophyllum decorum are of corticolous or epixylic in habitat found on the trees like Mangifera indica or Ficus virens due to rigid cortical cells and high moisture content in the region. The ability of mosses helps and enables them to occur on various habitats due to nutrient deficient trophic levels. This confirms that bryophytes can occur in wide range of different habitats (Slack, 1976).

\section{CONCLUSION:}

The distribution of bryophytes responds to topography, elevation, temperature, moisture as well as soil substrate and nutrients. At the higher altitude and maximum precipitation, rich bryophytes diversity observed in Gugamal, Chikhaldara, Semadoh and Belkund region. Most of the species occurs in pH range 6 to 8 i.e. slight acidic, neutral and slight basic nature. However, the distribution found variable among nutrient poor as well as nutrient rich vegetation. Hence, bryophyte species tends to be highly specific for particular microenvironment responding to temperature, light, humidity, precipitation and soil chemistry by making them good ecological indicator species. Considering the role of bryophytes in ecological succession in any ecosystem, much attention is now focused on this group by ecologists and conservation biologists.

\section{REFRENCES:}

Bates, J.W. (1982) The role of exchangeable calcium in saxicolous calcicole and calcifuge mosses. New Phytol. 90: 239-252

Bowen, R. and Rovira, P. (1999) The rhizosphere and its management to improved plant growth. Advances in Agronomy. 66: 1-102.

Brady, N. C. and Weil, R. R. (2008) The Nature and Properties of Soil, (14th ed.) Prentice Hall, New Delhi : 47-50.

Carling, D.E., Brown, M.F. and Brown, R.A. (1979) Colonization rates and growth responses of Soybean plants infected by VAM fungi, Soil Science Society of American Journal. 56: 789-794. 
Clymo, R.S. (1964) The origin of acidity in Sphagnum blogs. Bryologists. 67; 427-431.

Dhore, M.A. (2002) Flora of Amravati District with special reference to the distribution of tree species. (A Ph.D. thesis published by Amravati University, Amravati: 1-29.

Ganopadhyay, B.K., Das, P.K., Banerjee, S.P. and Banerjee, S.C. (1992) Characteristics of same lower and middle hills soil of South Sikkim forest. Indian Forester. 118 (9): 662-671.

Glime, J.M. (2006) Bryophyte Ecology Vol I, Michigan Technological University (USA), published online

at http://www.bryoecol:mtu.edu ; pp-31100.

Jackson, M.L. (1973) Soil Chemical Analysis, New Delhi: Prentice-Hall.: 239-241.

Jain, V.K. (2006) Fundamentals of Plant Physiology S. Chand and Company LTD, New Delhi: 101-110.

Jordan, C.F., Herrera, R., (1981) Tropical rainforests: are nutrients really critical ? Am. Nat. 117, 167-180.

Katznelson, H. (1965) Nature of importance of the rhizosphere; In; Baker, K.F. and Sydner, W.C (Eds.) "Ecology of soil borne plant pathogens”. John Murray Press: 88-96.

Kennedy, A.C. and Papendick, R.I. (1995) Microbial characteristics of soil quality. $J$. Soil Water Conser. 50: 243-248.
Mishra, R. (1968) Ecological Workbook. Calcutta: Oxford and IBH Publishing Company. 4496.

Nelson, D.W. and Sommers, L.E. (1996) Total carbon, organic carbon and organic matter. Methods of soil analysis. Part III, Chemical methods. Soil science Society of America Book. American Society of Agronomy, Madison. WI Series. 5: 9611010.

Patel, R.I. (1968) Forest Flora of Melghat. Bishen Singh Mahendra Pal Singh, Dehradun. (I): 4-12.

Ratnaparkhi, D.M. (2007) Community ecological studies in Melghat forest with emphasis an Eco-tourism. Ph.D. Thesis, Sant Gadge Baba Amravati University, Amravati (M.S.):41-50.

Shaw, J. and Renzaglia L. (2004) Phylogeny and diversification of Bryophytes. American Journal of Botany. 91 (10): 1557-1581.

Slack, N.G. (1976) Host Specificity of Bryophytic Epiphytes in Eastern North America. $J$. Hattori Bot. Lab. 41: 107-132.

Wang, G.M., Striple, D.B., Tunker, P.B., Walker, C. (1985) Soil pH and Vesicular Arbuscular Mycorrhizas, "Ecological Interaction in Soil", Blackwell Scientific Publication Oxford. U.K.: 219-234. 


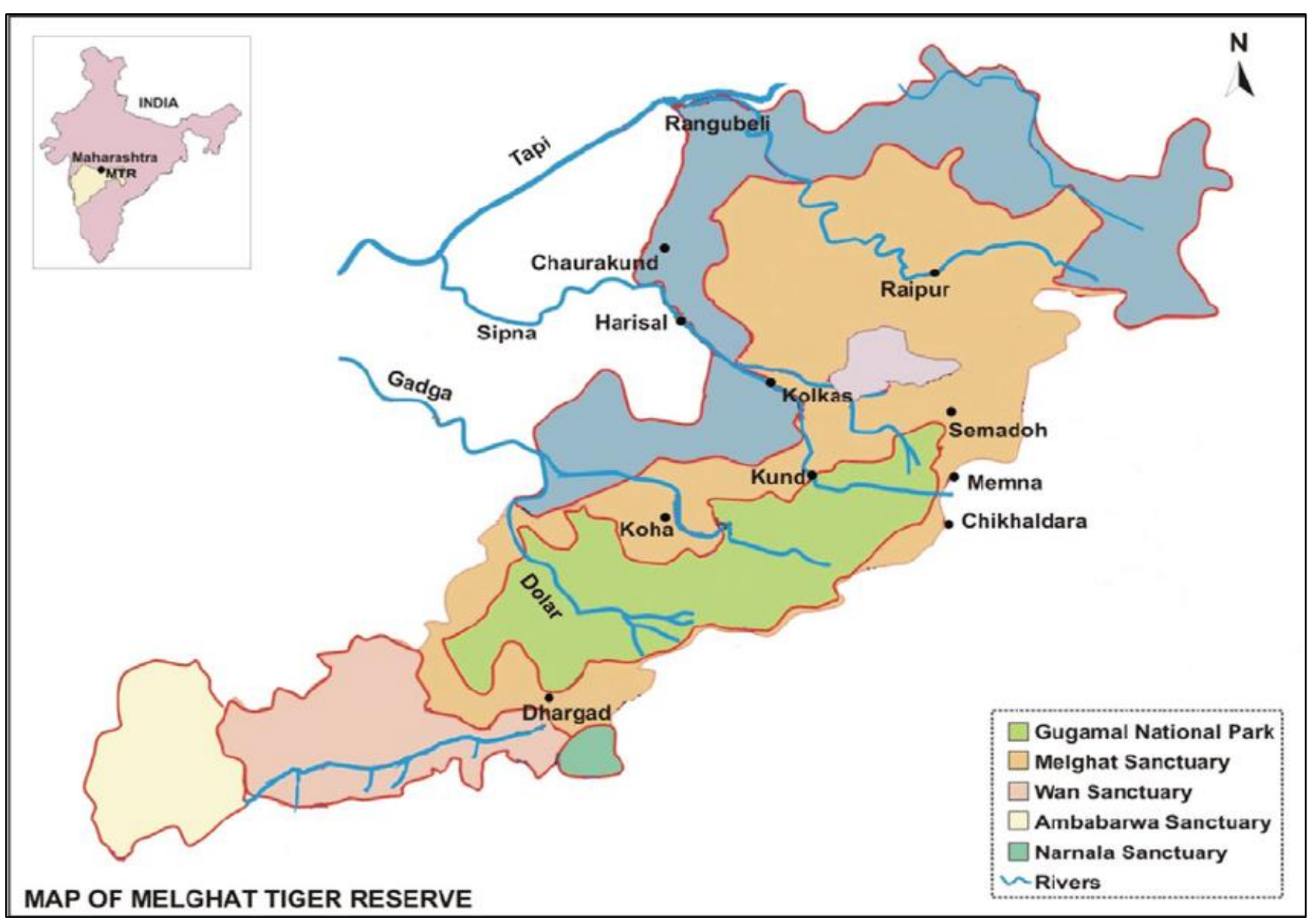

Fig 1. Melghat Forest Map 
Table: 1 Physico-chemical analysis of the soil attached to the plant thallus.

\begin{tabular}{|c|c|c|c|c|c|c|c|c|c|c|c|c|c|}
\hline $\begin{array}{l}\mathbf{S r} \\
\dot{\mathbf{N}} \\
\mathbf{O}\end{array}$ & Host Plant & 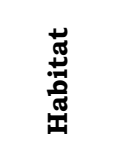 & ن & 莺总 & 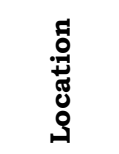 & 畧 & 영 ठ & 跑 & 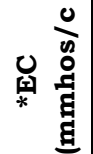 & 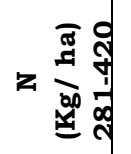 & 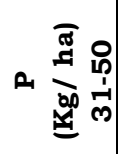 & 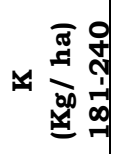 & 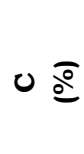 \\
\hline 1 & $\begin{array}{l}\text { Targionia } \\
\text { hypophylla }\end{array}$ & $\begin{array}{l}\text { Saxico } \\
\text { lous }\end{array}$ & $\begin{array}{l}\text { Blacki } \\
\text { sh }\end{array}$ & Clay & $\begin{array}{l}\text { Semad } \\
\text { oh }\end{array}$ & 6.73 & 19.2 & 009 & 0.13 & 134.1 & 44.09 & 428.64 & 0.35 \\
\hline 2 & $\begin{array}{l}\text { Cyathodium } \\
\text { tuberosum }\end{array}$ & $\begin{array}{l}\text { Terric } \\
\text { olous }\end{array}$ & $\begin{array}{l}\text { Blacki } \\
\text { sh }\end{array}$ & Clay & $\begin{array}{l}\text { Bhimk } \\
\text { und }\end{array}$ & 7.78 & 18.3 & 018 & 0.17 & 360.6 & 74.48 & 574.56 & 0.32 \\
\hline 3 & $\begin{array}{l}\text { Cyathodium } \\
\text { cavernarum }\end{array}$ & $\begin{array}{l}\text { Rupic } \\
\text { olous }\end{array}$ & $\begin{array}{l}\text { Brow } \\
\text { nish }\end{array}$ & $\begin{array}{l}\text { Laterit } \\
\text { ic }\end{array}$ & $\begin{array}{l}\text { Semad } \\
\text { oh }\end{array}$ & 7.12 & 20.1 & 012 & 0.25 & 329.0 & 34.44 & 504.4 & 0.29 \\
\hline 4 & $\begin{array}{l}\text { Asterella } \\
\text { angusta }\end{array}$ & $\begin{array}{l}\text { Saxico } \\
\text { lous }\end{array}$ & $\begin{array}{l}\text { Reddi } \\
\text { sh }\end{array}$ & $\begin{array}{l}\text { Bould } \\
\text { ery }\end{array}$ & $\begin{array}{l}\text { Belkun } \\
\text { d }\end{array}$ & 8.06 & 21.0 & 031 & 0.26 & 428.3 & 45.0 & 683.7 & 0.33 \\
\hline 5 & $\begin{array}{l}\text { Reboulia } \\
\text { hemisphaerica }\end{array}$ & $\begin{array}{l}\text { Terric } \\
\text { olous }\end{array}$ & $\begin{array}{l}\text { Reddi } \\
\mathrm{sh}\end{array}$ & $\begin{array}{l}\text { Laterit } \\
\text { ic }\end{array}$ & $\begin{array}{l}\text { Amaza } \\
\text { ri }\end{array}$ & 8.00 & 22 & 015 & 0.21 & 239.1 & 56.33 & 398.12 & 0.31 \\
\hline 6 & $\begin{array}{l}\text { Plagiochasma } \\
\text { appendiculatu } \\
m\end{array}$ & $\begin{array}{l}\text { Terric } \\
\text { olous }\end{array}$ & $\begin{array}{l}\text { Reddi } \\
\text { sh }\end{array}$ & $\begin{array}{l}\text { Bould } \\
\text { ery }\end{array}$ & $\begin{array}{l}\text { Chikha } \\
\text { ldara }\end{array}$ & 6.89 & 18 & 010 & 0.14 & 403.2 & 89.97 & 478.2 & 0.47 \\
\hline 7 & $\begin{array}{l}\text { Plagiochasma } \\
\text { intermedium }\end{array}$ & $\begin{array}{l}\text { Saxico } \\
\text { lous }\end{array}$ & $\begin{array}{l}\text { Whitis } \\
\mathrm{h}\end{array}$ & Lime & $\begin{array}{l}\text { Gawilg } \\
\text { arh }\end{array}$ & 8.00 & 16.2 & 009 & 0.21 & 211.1 & 14.60 & 398.1 & 0.31 \\
\hline 8 & $\begin{array}{l}\text { Plagiochasma } \\
\text { rupestre }\end{array}$ & $\begin{array}{l}\text { Terric } \\
\text { olous }\end{array}$ & $\begin{array}{l}\text { Brow } \\
\text { nish }\end{array}$ & $\begin{array}{l}\text { Laterit } \\
\text { ic }\end{array}$ & Koha & 7.42 & 19 & 026 & 0.16 & 501.7 & 47.93 & 668.6 & 0.32 \\
\hline 9 & $\begin{array}{l}\text { Riccia } \\
\text { gangetica }\end{array}$ & $\begin{array}{l}\text { Terric } \\
\text { olous }\end{array}$ & $\begin{array}{l}\text { Reddi } \\
\text { sh }\end{array}$ & $\begin{array}{l}\text { Laterit } \\
\text { ic }\end{array}$ & $\begin{array}{l}\text { Khong } \\
\text { ada }\end{array}$ & 7.56 & 20 & 012 & 0.29 & 239.1 & 41.52 & 396 & 0.41 \\
\hline 10 & Riccia discolor & $\begin{array}{l}\text { Terric } \\
\text { olous }\end{array}$ & $\begin{array}{l}\text { Blacki } \\
\text { sh }\end{array}$ & Clay & $\begin{array}{l}\text { Chura } \\
\text { ni }\end{array}$ & 7.55 & 23 & 016 & 0.35 & 236 & 58.14 & 436 & 0.35 \\
\hline 11 & $\begin{array}{l}\text { Anthoceros } \\
\text { erectus }\end{array}$ & $\begin{array}{l}\text { Terric } \\
\text { olous }\end{array}$ & $\begin{array}{l}\text { Blacki } \\
\text { sh }\end{array}$ & Clay & $\begin{array}{l}\text { Semad } \\
\text { oh }\end{array}$ & 7.18 & 24 & 009 & 0.18 & 266 & 102 & 346 & 0.34 \\
\hline 12 & $\begin{array}{l}\text { Folioceros } \\
\text { udarii }\end{array}$ & $\begin{array}{l}\text { Saxico } \\
\text { lous }\end{array}$ & $\begin{array}{l}\text { Reddi } \\
\text { sh }\end{array}$ & $\begin{array}{l}\text { Laterit } \\
\text { ic }\end{array}$ & $\begin{array}{l}\text { Semad } \\
\text { oh }\end{array}$ & 6.77 & 21 & 008 & $\begin{array}{l}0.07 \\
3\end{array}$ & 260 & 41.0 & 413 & 0.53 \\
\hline 13 & $\begin{array}{l}\text { Notothylas } \\
\text { indica }\end{array}$ & $\begin{array}{l}\text { Terric } \\
\text { olous }\end{array}$ & $\begin{array}{l}\text { Brow } \\
\text { nish }\end{array}$ & $\begin{array}{l}\text { Bould } \\
\text { ery }\end{array}$ & $\begin{array}{l}\text { Amaza } \\
\text { ri }\end{array}$ & 7.12 & 16 & 011 & 0.12 & 266 & 46.2 & 471 & 0.44 \\
\hline 14 & $\begin{array}{l}\text { Phaeoceros } \\
\text { laevis }\end{array}$ & $\begin{array}{l}\text { Terric } \\
\text { olous }\end{array}$ & $\begin{array}{l}\text { Blacki } \\
\text { sh }\end{array}$ & $\begin{array}{l}\text { Alluvi } \\
\text { um }\end{array}$ & $\begin{array}{l}\text { Semad } \\
\text { oh }\end{array}$ & 6.81 & 22 & 012 & 0.15 & 448 & 82.82 & 685.8 & 0.38 \\
\hline 15 & $\begin{array}{l}\text { Funaria } \\
\text { hygrometrica }\end{array}$ & $\begin{array}{l}\text { Terric } \\
\text { olous }\end{array}$ & $\begin{array}{l}\text { Brow } \\
\text { n Red }\end{array}$ & $\begin{array}{l}\text { Laterit } \\
\text { ic }\end{array}$ & $\begin{array}{l}\text { Gugam } \\
\text { al }\end{array}$ & 7.6 & 19 & 011 & 0.21 & 250 & 27.14 & 200.8 & 0.41 \\
\hline 16 & $\begin{array}{l}\text { Brachythemiu } \\
m \text { turgidum }\end{array}$ & $\begin{array}{l}\text { Epixyl } \\
\text { ic }\end{array}$ & $\begin{array}{l}\text { On } \\
\text { tree }\end{array}$ & $\begin{array}{l}\text { On } \\
\text { tree }\end{array}$ & $\begin{array}{l}\text { Gawilg } \\
\text { arh }\end{array}$ & - & - & - & - & - & - & - & - \\
\hline 17 & $\begin{array}{l}\text { Bryum } \\
\text { coronatum }\end{array}$ & $\begin{array}{l}\text { Terric } \\
\text { olous }\end{array}$ & $\begin{array}{l}\text { Ash- } \\
\text { black }\end{array}$ & $\begin{array}{l}\text { Gritty- } \\
\text { loam }\end{array}$ & $\begin{array}{l}\text { Ghata } \\
\text { ng }\end{array}$ & 6.89 & 26 & 012 & 0.09 & 241 & 32.87 & 680 & 0.47 \\
\hline 18 & $\begin{array}{l}\text { Stereophyllum } \\
\text { decorum }\end{array}$ & $\begin{array}{l}\text { Epixyl } \\
\text { ic }\end{array}$ & $\begin{array}{l}\text { On } \\
\text { tree }\end{array}$ & $\begin{array}{l}\text { On } \\
\text { tree }\end{array}$ & Bori & - & - & - & - & - & - & - & - \\
\hline 19 & $\begin{array}{l}\text { Hyophila } \\
\text { involuta }\end{array}$ & $\begin{array}{l}\text { Epilith } \\
\text { ic }\end{array}$ & $\begin{array}{l}\text { Brow } \\
\text { nish }\end{array}$ & $\begin{array}{l}\text { Laterit } \\
\text { ic }\end{array}$ & $\begin{array}{l}\text { Kolkha } \\
\text { s }\end{array}$ & 7.85 & 24 & 013 & 0.25 & 321 & 16.50 & 463 & 0.37 \\
\hline 20 & $\begin{array}{l}\text { Hymenostyliu } \\
\text { m recurvirostre }\end{array}$ & $\begin{array}{l}\text { Epilith } \\
\text { ic }\end{array}$ & $\begin{array}{l}\text { Blacki } \\
\text { sh }\end{array}$ & Clay & Madaki & 6.90 & 29.1 & 017 & 0.14 & 230 & 14.50 & 390 & 0.43 \\
\hline
\end{tabular}

